\title{
ANALISIS TRIWULANAN: \\ PERKEMBANGAN MONETER, PERBANKAN DAN SISTEM PEMBAYARAN, TRIWULAN IV - 2014
}

\author{
Tim Penulis Laporan Triwulanan, Bank Indonesia
}

Perekonomian Indonesia pada triwulan IV 2014 menunjukkan bahwa stabilitas makroekonomi dan sistem keuangan yang terjaga. Kondisi ini tercermin pada defisit transaksi berjalan yang menurun dan inflasi yang terkendali. Sementara itu, ekonomi domestik tumbuh meningkat dibandingkan dengan triwulan sebelumnya, meskipun secara keseluruhan 2014 melambat. Kinerja transaksi berjalan triwulan IV 2014 membaik terutama didukung oleh surplus neraca perdagangan nonmigas dan menurunnya defisit neraca perdagangan migas. Di sisi lain, stabilitas sistem keuangan tetap solid ditopang oleh ketahanan sistem perbankan dan relatif terjaganya kinerja pasar keuangan.

\section{Perkembangan Global}

Pemulihan perekonomian global diperkirakan masih berlangsung meskipun berjalan tidak merata. Ekonomi AS diperkirakan akan tumbuh lebih tinggi dari perkiraan semula. Sementara itu, ekonomi Jepang dan Tiongkok diperkirakan tumbuh lebih rendah dari perkiraan sebelumnya. Pemulihan ekonomi Eropa diperkirakan masih berjalan lambat seiring dengan tingkat keyakinan konsumen yang menurun dan ancaman deflasi. Kondisi tersebut telah mendorong European Central Bank (ECB) melakukan stimulus perekonomian melalui kebijakan Expanded Asset Purchase Program (EAPP). Rencana kebijakan stimulus moneter tersebut diperkirakan akan mendorong arus modal portofolio asing ke emerging market termasuk Indonesia, meskipun berpotensi menimbulkan ketidakpastian dan volatilitas di pasar keuangan global.

Perekonomian AS tumbuh lebih baik dari perkiraan sebelumnya terutama didukung oleh penguatan permintaan domestik. Penguatan permintaan domestik, yang tercermin dari kenaikan indeks keyakinan konsumen, didorong oleh kenaikan pendapatan riil akibat semakin menurunnya harga minyak dan perbaikan sektor tenaga kerja. Harga minyak yang menurun di tengah konsumsi minyak AS yang besar diperkirakan dapat menopang berlanjutnya perbaikan ekonomi AS. Perbaikan sektor tenaga kerja tercermin dari tingkat pengangguran yang terus menurun mencapai 5,6\%, sejalan dengan pertumbuhan lowongan pekerjaan baru (job openings) yang terus meningkat (Grafik 1).

Pemulihan ekonomi Eropa diperkirakan masih berjalan lambat. Lambatnya pemulihan ekonomi Eropa tersebut terindikasi dari tren penurunan indeks manufaktur PMI Eropa. PMI Italia dan Perancis masih berada pada fase kontraksi, sementara PMI Jerman dan Spanyol 
telah menunjukkan indikasi ekspansi. Sejalan dengan perkembangan tersebut, kawasan Eropa memasuki zona deflasi sejak Desember 2014 (Grafik 2). Dalam rangka mempercepat pemulihan ekonomi Eropa, otoritas moneter Eropa (ECB) akan melakukan program quantitative easing berupa program pembelian aset (EAPP) sebesar 60 miliar euro setiap bulannya dimulai sejak Maret 2015 hingga September 2016. Stimulus moneter tersebut diprediksi dapat menambah likuiditas global, meskipun tambahan arus masuk modal portofolio ke negara EM, termasuk Indonesia, tidak sebesar arus modal masuk sebagai dampak dari program QE the Fed pada tahun 2008 lalu.

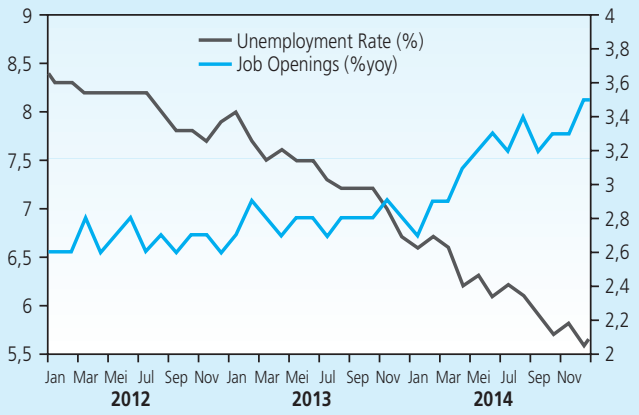

Grafik 1.

Tingkat Pengangguran dan Job Opening AS

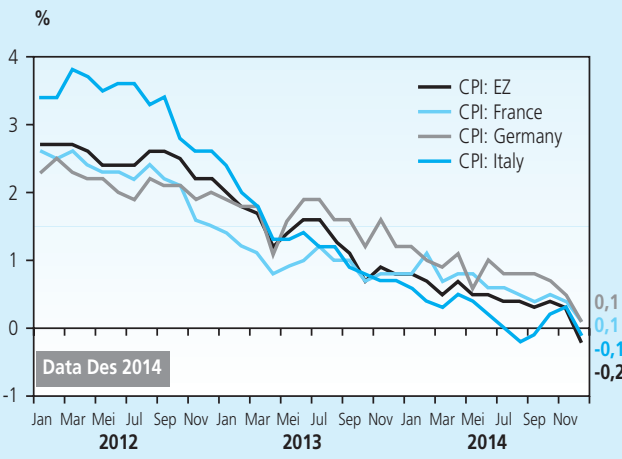

Grafik 2. Tingkat Inflasi Eropa

Perekonomian Jepang tumbuh lebih rendah dari perkiraan semula. Hal tersebut tercermin dari masih lemahnya pertumbuhan konsumsi. Tingkat penjualan ritel masih lemah dan tingkat keyakinan konsumen berada dalam tren menurun. Sementara itu, sektor tenaga kerja juga belum menunjukkan dukungan terhadap kenaikan permintaan. Tingkat job hires berada dalam tren yang menurun dan pertumbuhan gaji masih lemah. Di sisi lain, kebijakan quantitative easing oleh Bank of Japan berdampak positif terhadap depresiasi Yen yang mendukung peningkatan pertumbuhan ekspor Jepang. Ke depan, kinerja perekonomian Jepang diperkirakan membaik, didukung berbagai kebijakan Pemerintah, seperti stimulus sebesar 3,5 triliun yen, insentif penurunan pajak bagi perusahaan yang menaikkan gaji karyawan, dan reformasi struktural (Abe's 3rd arrow).

Kinerja perekonomian Tiongkok diperkirakan melambat dan tumbuh lebih rendah dari perkiraan sebelumnya. Melambatnya pertumbuhan Tiongkok terutama didorong oleh tren penurunan pertumbuhan investasi, yang tercermin pada menurunnya indikator investasi aset tetap (Grafik 3). Selain investasi, indikator konsumsi yaitu penjualan ritel masih berada dalam tren menurun. Dari sisi produksi, indeks produksi mencatat penurunan dan indikator PMI Manufaktur 
menunjukkan tren penurunan dan memasuki zona kontraksi. Potensi berlanjutnya perlambatan ekonomi Tiongkok juga terindikasi dari masih besarnya downside risk pada sektor perumahan (harga properti/perumahan masih lemah) dan meningkatnya risiko deleveraging.

Kinerja perekonomian India terus membaik namun diperkirakan sedikit lebih rendah dari perkiraan semula. Hal ini sejalan dengan permintaan eksternal yang lebih lemah khususnya dari Tiongkok. Meskipun demikian, dampak negatif dari lemahnya permintaan eksternal diimbangi oleh meningkatnya Terms of Trade akibat penurunan harga minyak. Di sisi lain, aktivitas investasi dan industri meningkat pasca penerapan kebijakan kebijakan reformasi. Hal ini tercermin dari meningkatnya indeks produksi dan manufaktur. Kondisi tersebut juga turut mendorong meningkatnya tingkat keyakinan bisnis (Grafik 4).

Di sisi pasar keuangan global, potensi ketidakpastian dan volatilitas di pasar keuangan global muncul seiring dengan rencana kebijakan stimulus moneter yang akan dilakukan oleh Bank Sentral Eropa. Ketidakpastian terkait pelaksanaan EAPP tersebut dipengaruhi oleh proses eksekusinya yang relatif sulit karena melibatkan banyak bank sentral di Eurozone dan faktor risiko politik di Eropa seperti Yunani. Hal ini seiring dengan perkembangan pertumbuhan ekonomi negara-negara EM yang melemah sehingga mendorong tambahan likuiditas dari Eropa untuk masuk dalam investasi AS dengan yield yang lebih tinggi. Kondisi ini akan mendorong penguatan dolar AS yang berpotensi menimbulkan volatilias di pasar keuangan global.

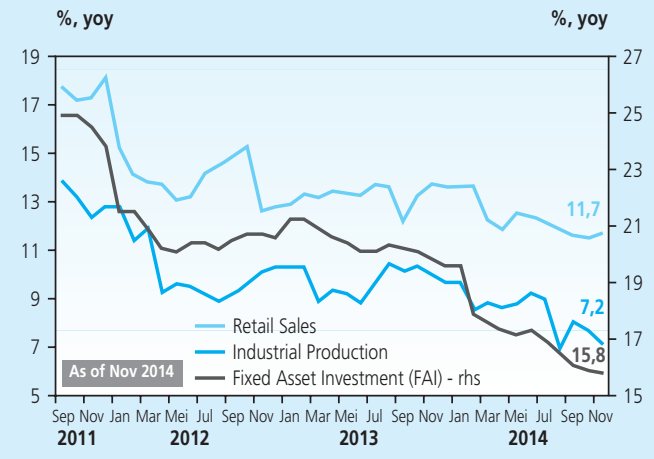

Grafik 3.

Perkembangan Investasi dan Konsumsi Tiongkok

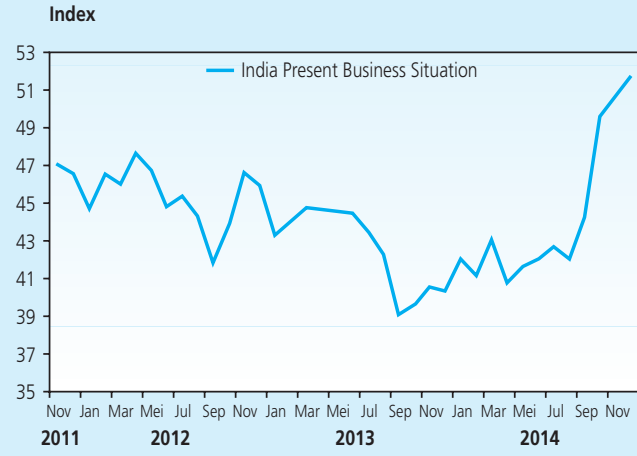

Grafik 4.

Tingkat Keyakinan Bisnis India

\section{Pertumbuhan Ekonomi}

Pertumbuhan ekonomi Indonesia pada triwulan IV 2014 meningkat dibandingkan triwulan sebelumnya, meskipun secara keseluruhan tahun pertumbuhan ekonomi Indonesia 2014 melambat. Pertumbuhan ekonomi triwulan IV 2014 sebesar 5,01\% (yoy) yang meningkat dibandingkan triwulan sebelumnya sebesar 4,92\% (yoy) (Tabel 1) mengindikasikan bahwa 
siklus perlambatan ekonomi yang berlangsung sejak beberapa tahun terakhir telah melewati titik terendahnya pada triwulan III 2014. Perbaikan pertumbuhan ekonomi tersebut terutama didorong oleh meningkatnya permintaan domestik, khususnya investasi bangunan dan konsumsi pemerintah. Sementara itu, konsumsi rumah tangga masih tetap kuat, meskipun sedikit melambat sejalan dengan kebijakan stabilisasi ekonomi. Di sisi eksternal, kinerja ekspor mencatat kontraksi yang cukup dalam, terutama akibat melemahnya permintaan negara emerging dan menurunnya harga komoditas. Meskipun pada triwulan IV 2014 sudah mulai membaik, secara keseluruhan pada 2014 pertumbuhan masih melambat menjadi 5,02\%, lebih rendah dari tahun sebelumnya, sejalan dengan lemahnya pertumbuhan ekonomi global dan kebijakan stabilisasi makroekonomi. Secara spasial, perlambatan ekonomi terutama terjadi di sejumlah daerah penghasil SDA tambang, antara lain, Provinsi Aceh, Kalimantan Timur, Riau, dan Papua. Sementara itu, kinerja daerah yang mengandalkan sektor manufaktur seperti Jawa dan Jakarta masih tumbuh relatif cukup kuat.

\begin{tabular}{|c|c|c|c|c|c|c|c|c|c|c|}
\hline \multicolumn{11}{|c|}{$\begin{array}{c}\text { Tabel } 1 \\
\text { Pertumbuhan Ekonomi Sisi Pengeluaran (\%,yoy) }\end{array}$} \\
\hline \multirow{3}{*}{ Komponen } & \multicolumn{10}{|c|}{ \%Y-o-Y, Tahun Dasar 2010} \\
\hline & \multicolumn{4}{|c|}{2013} & \multirow{2}{*}{2013} & \multicolumn{4}{|c|}{2014} & \multirow{2}{*}{2014} \\
\hline & $\mathrm{I}$ & II & III & IV & & I & II & III & IV & \\
\hline Konsumsi Rumah Tangga & 5,52 & 5,25 & 5,35 & 5,41 & 5,38 & 5,35 & 5,14 & 5,08 & 5,01 & 5,14 \\
\hline Konsumsi LNPRT & 6,51 & 6,43 & 6,70 & 12,81 & 8,18 & 23,66 & 22,79 & 5,64 & $(-0,23)$ & 12,43 \\
\hline Konsumsi Pemerintah & 3,02 & 3,20 & 12,44 & 7,89 & 6,93 & 6,12 & $(-1,50)$ & 1,33 & 2,83 & 1,98 \\
\hline Pembentukan Modal Tetap Domestik Bruto & 7,95 & 5,52 & 6,00 & 2,10 & 5,28 & 4,66 & 3,71 & 3,86 & 4,27 & 4,12 \\
\hline Ekspor Barang dan Jasa & 3,50 & 2,10 & 1,34 & 9,44 & 4,17 & 3,16 & 1,38 & 4,86 & $(-4,53)$ & 1,02 \\
\hline Impor Barang dan Jasa & 2,92 & 0,88 & 4,93 & $(-0,85)$ & 1,86 & 5,04 & 0,41 & 0,28 & 3,22 & 2,19 \\
\hline PDB & 5,61 & 5,59 & 5,50 & 5,61 & 5,58 & 5,14 & 5,03 & 4,92 & 5,01 & 5,02 \\
\hline
\end{tabular}

Meskipun tetap kuat, konsumsi rumah tangga pada triwulan IV 2014 masih melanjutkan tren perlambatan sejalan dengan kebijakan stabilisasi makroekonomi. Konsumsi rumah tangga tumbuh melambat dari 5,08\% (yoy) pada triwulan III 2014 menjadi 5,01\% (yoy) pada triwulan IV 2014. Perlambatan konsumsi rumah tangga didorong oleh melemahnya daya beli, sejalan dengan peningkatan inflasi akibat kenaikan harga BBM serta melambatnya pendapatan yang bersumber dari hasil ekspor. Selain itu, konsumsi juga tertahan oleh kebijakan stabilisasi makroekonomi. Melemahnya daya beli tersebut tercermin dari menurunnya keyakinan konsumen atas kondisi ekonomi dan melemahnya ekspektasi penghasilan masyarakat. Sementara itu, melambatnya konsumsi rumah tangga terlihat dari pertumbuhan indikator penjualan eceran yang melambat dan kontraksi penjualan mobil dan motor pada triwulan IV 2014.

Berbeda dengan konsumsi rumah tangga, konsumsi pemerintah tumbuh meningkat pada triwulan IV 2014. Pertumbuhan konsumsi pemerintah tercatat sebesar 2,83\% (yoy), meningkat 
dibandingkan dengan triwulan III 2014 yang tumbuh sebesar 1,33\% (yoy). Peningkatan pertumbuhan konsumsi pemerintah tersebut terutama didorong oleh meningkatnya belanja pegawai.

Kinerja investasi meningkat ditopang oleh investasi bangunan yang tumbuh tinggi. Investasi tumbuh meningkat secara gradual dari 3,86\% (yoy) pada triwulan III 2014 menjadi 4,27\% (yoy) pada triwulan IV 2014. Pertumbuhan investasi terutama ditopang oleh kinerja investasi bangunan yang tumbuh tinggi sebesar 7,06\% (yoy), sejalan dengan mulai meningkatnya aktivitas investasi paska Pemilu. Perkembangan ini tercermin pada impor bahan bangunan yang meningkat dan penjualan semen yang tumbuh stabil. Namun, pertumbuhan investasi masih tertahan oleh kontraksi investasi nonbangunan, sejalan dengan kinerja konsumsi rumah tangga yang melambat dan ekspor yang terkontraksi. Kontraksi investasi non bangunan terindikasi pada impor barang modal dan penjualan alat berat domestik yang masih menurun pada triwulan IV 2014.

Di sisi eksternal, kinerja ekspor mencatat kontraksi yang cukup dalam, terutama akibat melemahnya permintaan negara emerging dan menurunnya harga komoditas. Ekspor pada triwulan IV 2014 mencatat kontraksi 4,53\% (yoy), jauh lebih rendah dari pertumbuhan positif pada triwulan sebelumnya $(4,86 \%$, yoy) Hal ini diakibatkan oleh melemahnya permintaan negara emerging (Grafik 5) dan menurunnya harga komoditas. Selain itu, kontraksi ekspor juga dipengaruhi oleh dampak perhitungan dasar (base effect) dari tingginya ekspor pertambangan pada triwulan IV 2013 menjelang penerapan UU Minerba pada awal 2014 (Grafik 6). Meskipun secara keseluruhan ekspor menurun, ekspor manufaktur masih menunjukkan kinerja yang positif sejalan dengan terus berlanjutnya pemulihan ekonomi AS dan perkembangan nilai tukar Rupiah yang sesuai dengan nilai fundamentalnya.

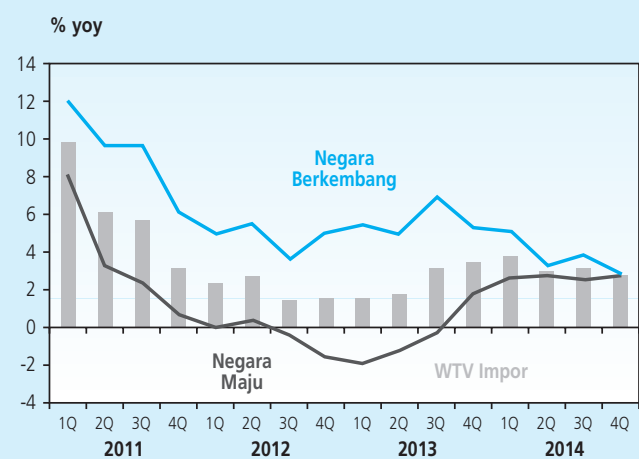

Sumber: CPB World TRade Monitor (diolah)

Grafik 5. Volume Perdagangan (Impor) Dunia

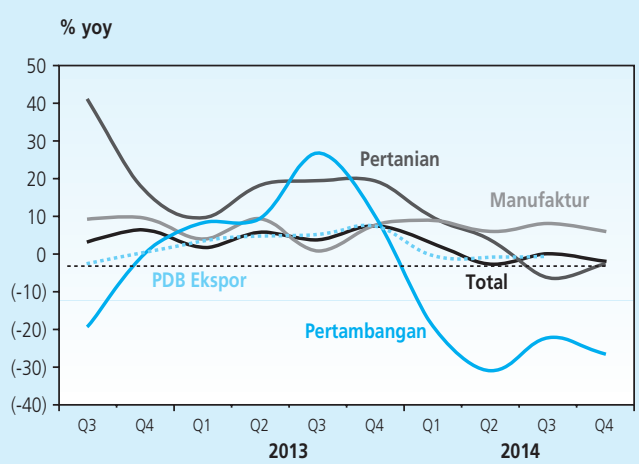

Grafik 6. Pertumbuhan Ekspor Nonmigas Riil 
Kinerja impor pada triwulan IV 2014 meningkat sebagai respons peningkatan permintaan domestik. Impor tercatat tumbuh 3,22\% (yoy), meningkat dibandingkan dengan pertumbuhan triwulan sebelumnya sebesar 0,28\% (yoy). Dari sisi nonmigas, impor bahan baku meningkat sejalan dengan meningkatnya kebutuhan bahan baku untuk sektor industri guna memenuhi kenaikan permintaan domestik. Selain itu, peningkatan impor juga didorong oleh peningkatan impor migas seiring dengan langkah antisipasi Pertamina menghadapi kenaikan konsumsi terkait rencana kenaikan harga BBM bersubsidi pada pertengahan bulan November 2014.

Pada triwulan IV 2014, peningkatan perekonomian nasional tercermin pada perbaikan sejumlah sektor ekonomi ${ }^{1}$ khususnya sektor nontradable. Peningkatan sektor nontradable terutama didorong oleh pertumbuhan sektor bangunan yang menguat seiring dengan meningkatnya optimisme terhadap pemerintahan baru. Di sisi lain, kinerja sektor tradable tumbuh melambat dibandingkan triwulan sebelumnya. Sektor pertanian tumbuh melambat sebagai dampak dari menurunnya luas panen padi terkait pengalihan lahan ke jagung dan kedelai. Sementara itu, sektor industri juga tumbuh melambat, sejalan dengan kecenderungan melemahnya konsumsi swasta dan melambatnya ekspor di penghujung tahun 2014.

Secara spasial, pemulihan ekonomi nasional pada triwulan IV 2014 terutama didorong oleh perbaikan kinerja ekonomi di Wilayah Jawa (Gambar 1). Perbaikan kinerja ekonomi berbagai daerah di Wilayah Jawa ditopang oleh masih cukup kuatnya kinerja industri pengolahan. Perbaikan kinerja ekonomi juga terjadi di Kalimantan seiring dengan peningkatan aktivitas di sektor pertambangan, meskipun masih terbatas karena insentif harga yang masih rendah. Sementara itu, kinerja ekonomi berbagai daerah di Sumatera, mulai tumbuh stabil ditopang oleh kinerja perkebunan yang membaik. Sementara itu, kinerja pertumbuhan ekonomi wilayah timur Indonesia, masih tertahan karena kontraksi kinerja pertambangan di beberapa daerah, seperti Papua, Papua Barat, Sulawesi Tenggara, dan Sulawesi Tengah.

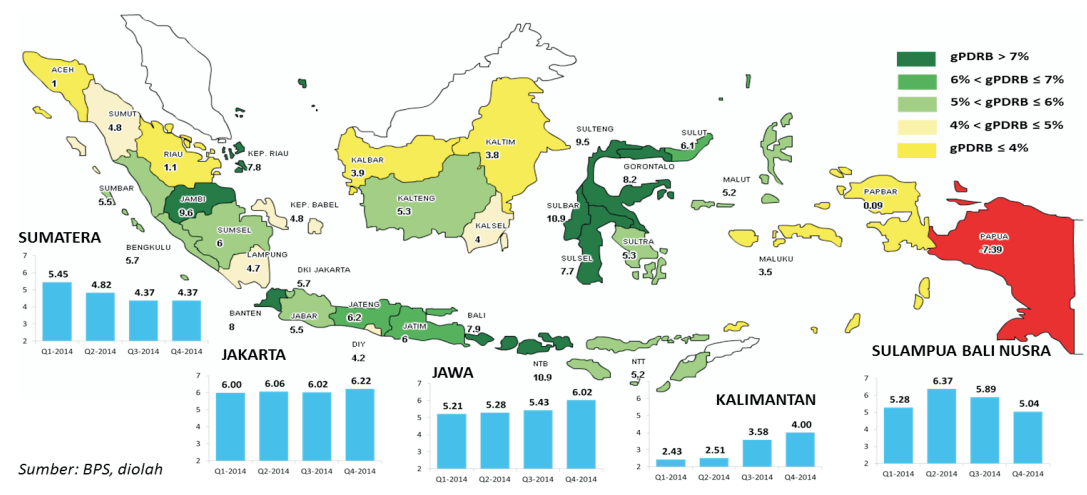

Gambar 1.

Peta Pertumbuhan Ekonomi Daerah Triwulan IV 2014

1 Publikasi PDB oleh BPS pada 5 Februari 2015 telah menggunakan perhitungan tahun dasar baru 2010 dan juga menerapkan System of National Accounts 2008 (SNA2008). Berdasarkan konsep SNA tersebut, terdapat perubahan klasifikasi PDB menurut lapangan usaha yaitu menjadi 17 lapangan usaha, dari sebelumnya 9 sektor. 


\section{Neraca Pembayaran Indonesia}

Kinerja Neraca Pembayaran Indonesia (NPI) membaik pada triwulan IV 2014, terutama didukung oleh defisit transaksi berjalan yang menurun. Secara keseluruhan, neraca NPI triwulan IV 2014 mencatat surplus sebesar 2,4 miliar dolar AS (Grafik 7). Surplus ini ditopang oleh transaksi berjalan yang menurun dan masih cukup besarnya surplus transaksi modal dan finansial. Surplus NPI triwulan IV-2014 tersebut pada gilirannya mendorong kenaikan posisi cadangan devisa dari 111,2 miliar dolar AS pada akhir triwulan III 2014 menjadi 111,9 miliar dolar AS pada akhir triwulan IV 2014 (Grafik 8). Jumlah cadangan devisa tersebut cukup untuk membiayai kebutuhan pembayaran impor dan utang luar negeri Pemerintah selama 6,4 bulan dan berada di atas standar kecukupan internasional. Pada Januari 2015, posisi cadangan devisa kembali meningkat menjadi 114,2 miliar dolar AS.

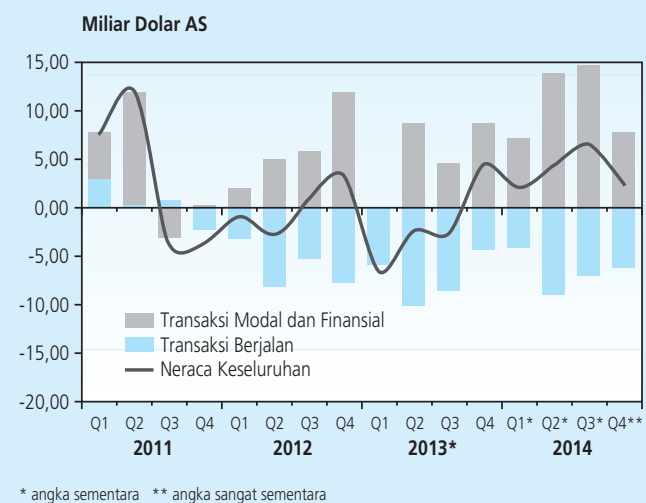

Grafik 7.

Neraca Pembayaran Indonesia

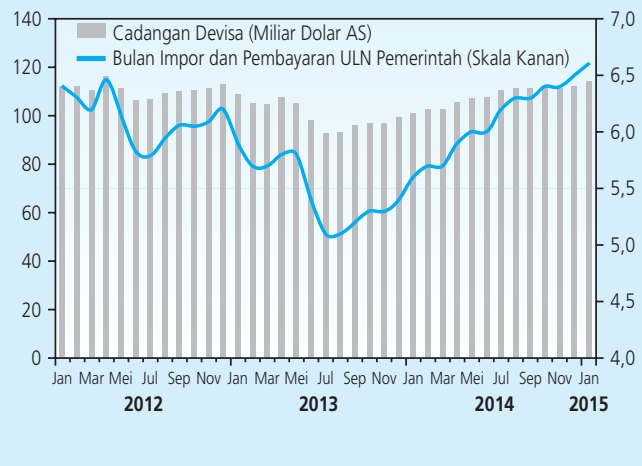

Grafik 8.

Perkembangan Cadangan Devisa

Di tengah proses pemulihan global yang lebih lambat dari perkiraan, kinerja transaksi berjalan membaik. Defisit transaksi berjalan triwulan IV 2014 tercatat sebesar 6,2 miliar dolar AS (2,81\% PDB), lebih rendah dibandingkan dengan defisit 7,0 miliar dolar AS (2,99\% PDB) pada triwulan III 2014. Perbaikan kinerja transaksi berjalan tersebut terutama didukung oleh meningkatnya surplus neraca perdagangan barang seiring naiknya surplus neraca perdagangan nonmigas dan menurunnya defisit neraca perdagangan migas. Surplus neraca perdagangan nonmigas meningkat ditopang oleh kenaikan ekspor, khususnya minyak nabati dan produk manufaktur. Di sisi migas, meskipun volume impor minyak meningkat, defisit neraca perdagangan migas menyusut sebagai dampak dari terus melemahnya harga minyak mentah dunia. Pada Januari 2015, neraca perdagangan mencatat surplus sebesar 0,7 miliar dolar AS, lebih tinggi dari bulan sebelumnya, didukung oleh menurunnya defisit neraca perdagangan migas. 
Sementara itu, persepsi positif investor terhadap prospek ekonomi Indonesia mendorong aliran masuk modal asing yang cukup besar dan mampu membiayai defisit transaksi berjalan. Pada triwulan IV 2014, surplus transaksi modal dan finansial didukung oleh aliran masuk investasi langsung asing (FDI) dan surplus investasi lainnya yang berasal dari penarikan simpanan penduduk di luar negeri dan penarikan pinjaman LN korporasi. Namun demikian, surplus transaksi modal dan finansial ini masih lebih rendah dibandingkan dengan surplus triwulan III 2014. Penurunan tersebut antara lain disebabkan keluarnya dana asing dari instrumen portofolio rupiah di bulan Desember 2014, dipicu oleh meningkatnya kekhawatiran investor terkait rencana kenaikan Fed Fund Rate akibat rilis data perbaikan ekonomi AS.

\section{Nilai Tukar Rupiah}

Nilai tukar Rupiah melemah seiring dengan apresiasi dolar AS yang terjadi secara luas. Pada triwulan IV 2014, rupiah secara rata-rata melemah sebesar 3,9\% (qtq) ke level Rp12.244 per dolar AS (Grafik 9). Semakin solidnya perekonomian AS mendorong penguatan dolar AS terhadap seluruh mata uang dunia (Grafik 10).

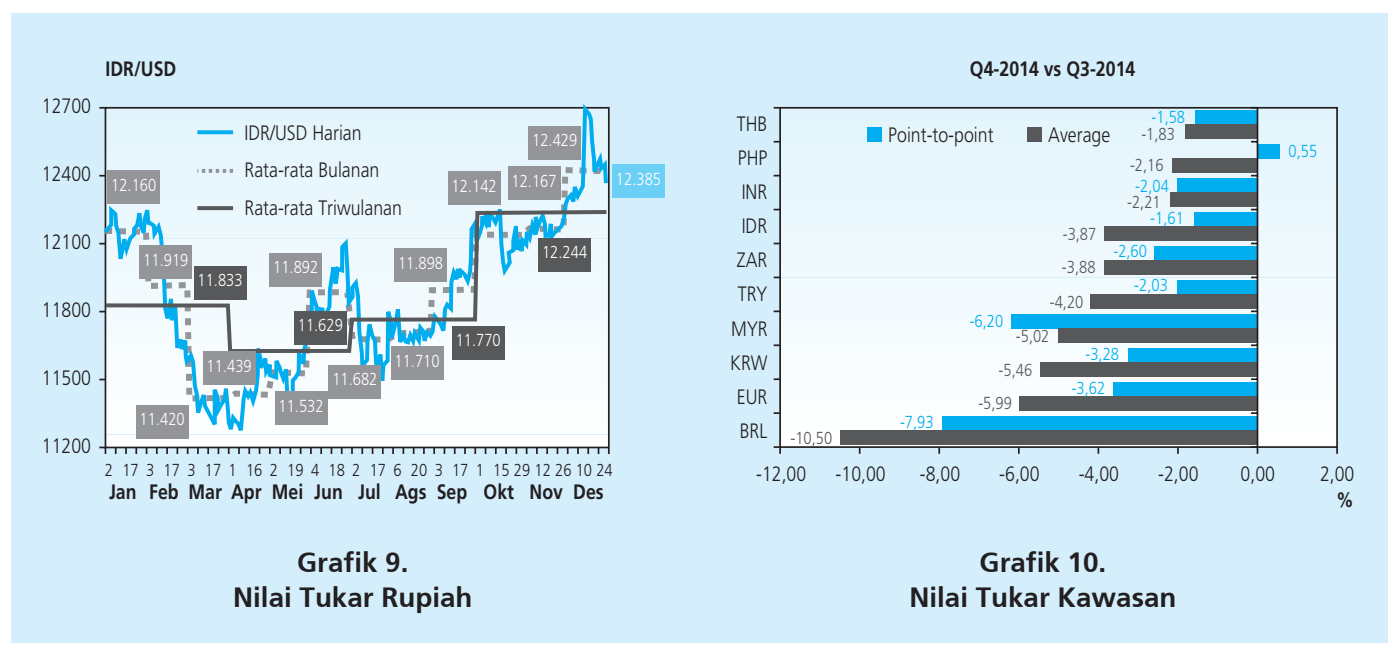

\section{Inflasi}

Inflasi tetap terjaga dan mendukung prospek pencapaian sasaran inflasi 2015 yakni 4,0 \pm 1\%. Inflasi triwulan IV 2014 tercatat sebesar 4,49\% (qtq) atau 8,36\% (yoy), meningkat dibandingkan triwulan III 2014 sebesar 1,68\% (qtq) atau 4,53\% (yoy) (Grafik 11). Peningkatan inflasi terutama didorong oleh kenaikan harga BBM bersubsidi dan gejolak harga pangan domestik pada akhir tahun 2014. Namun demikian, inflasi inti pada triwulan IV 2014 tetap terkendali sebesar 4,93\% (yoy). Hal ini tidak terlepas dari semakin baiknya koordinasi pengendalian inflasi antara Bank Indonesia dan Pemerintah. 
Tekanan inflasi volatile food meningkat pada triwulan IV 2014 akibat terbatasnya pasokan komoditas aneka cabai dan beras. Inflasi kelompok volatile food tercatat sebesar 6,23\% (qtq) atau 10,88\% (yoy), lebih tinggi dibandingkan inflasi triwulan sebelumnya sebesar 2,11\% (qtq) atau 4,21\% (yoy). Kenaikan inflasi tersebut terutama didorong oleh terbatasnya pasokan, khususnya untuk komoditas aneka cabai dan beras akibat kekeringan pada akhir September sampai awal November, serta curah hujan yang tinggi pada akhir November sampai Desember. Tekanan harga volatile food juga didorong oleh peningkatan biaya distribusi akibat cost-push dari kenaikan harga BBM bersubsidi pada pertengahan November 2014. Selain itu, kekosongan Raskin pada bulan November dan Desember juga turut berdampak pada meningkatnya tekanan harga volatile food pada triwulan IV ini.

Tekanan inflasi administered prices meningkat pada triwulan IV 2014 terutama didorong oleh kenaikan harga BBM bersubsidi. Pada triwulan IV 2014, inflasi kelompok administered prices meningkat dari $2,51 \%$ (qtq) atau $6,53 \%$ (yoy) menjadi 12,03\% (qtq) atau 17,57\% (yoy). Kebijakan Pemerintah menaikkan harga BBM bersubsidi pada 18 November 2014 mendorong kenaikan harga baik secara langsung maupun tidak langsung (second round effect) terhadap tarif angkutan. Selain itu, sumber tekanan inflasi kelompok administered prices sepanjang triwulan IV 2014 juga berasal dari kenaikan tarif tenaga listrik (TTL), kenaikan Bahan Bakar Rumah Tangga (BBRT), serta kenaikan tarif angkutan udara.

Inflasi inti tetap terkendali pada triwulan IV 2014, meskipun terdapat tekanan dari eksternal dan domestik. Inflasi inti tercatat sebesar 1,70\% (qtq) atau 4,93\% (yoy), sedikit meningkat dibandingkan triwulan sebelumnya sebesar 1,28\% (qtq) atau 4,04\% (yoy). Tekanan eksternal terutama disebabkan oleh pelemahan Rupiah, meskipun masih tertahan oleh penurunan harga global seperti tercermin pada penurunan indeks harga imported inflation (IHIM). Di sisi lain, tekanan dari domestik lebih disebabkan oleh faktor cost push kenaikan harga BBM bersubsidi, sementara tekanan permintaan cenderung terjaga sejalan dengan pertumbuhan ekonomi yang melambat.

Inflasi inti yang terjaga pada triwulan IV 2014 turut didukung oleh ekspektasi inflasi yang terkendali baik di level pedagang eceran maupun konsumen. Pada level pedagang eceran, kenaikan ekspektasi inflasi setelah realisasi kenaikan BBM pada November 2014 menunjukkan tekanan harga yang lebih rendah baik untuk 3 bulan mendatang maupun 6 bulan mendatang dibandingkan episode kenaikan BBM tahun 2013 (Grafik 12). Selain itu, ekspektasi inflasi di tingkat konsumen untuk 3 bulan mendatang dan 6 bulan mendatang menunjukkan penurunan seiring dengan keyakinan dampak BBM akan bersifat temporer (3 bulan sejak November) dan optimisme ketersediaan barang yang lebih baik di tahun depan. 


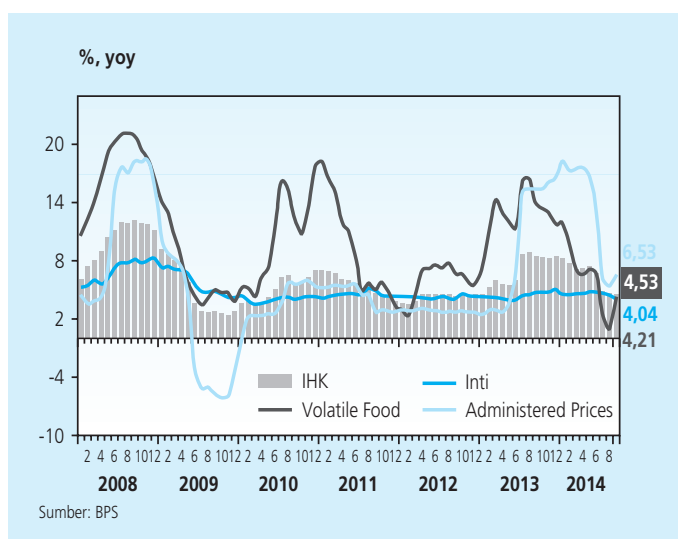

Grafik 11.

Perkembangan Inflasi Tahunan

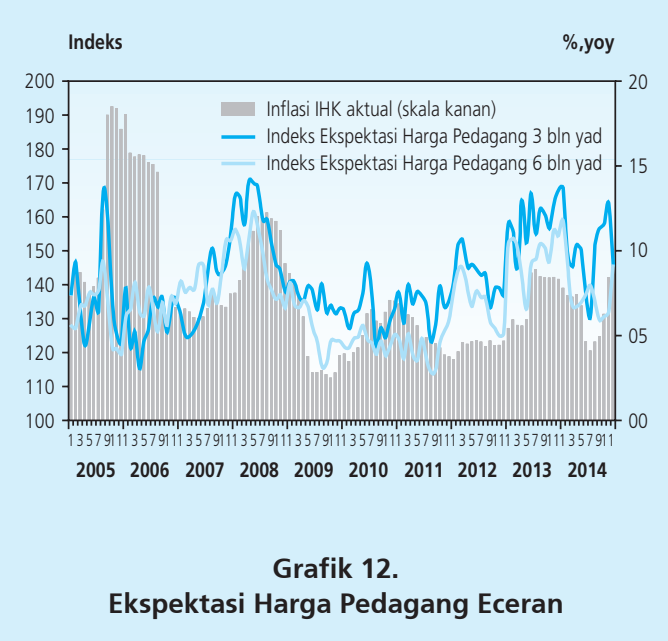

Secara spasial, tekanan inflasi pada triwulan IV 2014 mengalami peningkatan di berbagai daerah. Tekanan inflasi cukup tinggi dan merata hampir di seluruh provinsi pada triwulan IV 2014 (Gambar 2). Tekanan inflasi tertinggi terjadi di wilayah Sulawesi-Maluku-Papua, BaliNusa Tenggara serta Jakarta. Namun, pada Januari 2015 sebagian besar daerah di Sumatera dan Jawa tercatat mengalami deflasi, meskipun beberapa daerah di kawasan lainnya masih mengalami inflasi. Deflasi terdalam terjadi di Sumatera Barat, didorong koreksi harga cabe merah yang signifikan dan mulai terjadinya koreksi harga beras seiring masuknya masa panen. Sementara di Jawa, deflasi yang cukup besar terjadi di Jakarta karena penurunan harga BBM dan pasokan cabai merah yang meningkat. Namun demikian, beberapa daerah mencatat kenaikan inflasi seperti Maluku, Nusa Tenggara Timur, dan sebagian besar daerah di Kalimantan. Inflasi tersebut terutama disebabkan oleh kenaikan harga ikan segar, Bahan Bakar Rumah Tangga serta beberapa komoditas bahan makanan seperti daging ayam dan sayuran.

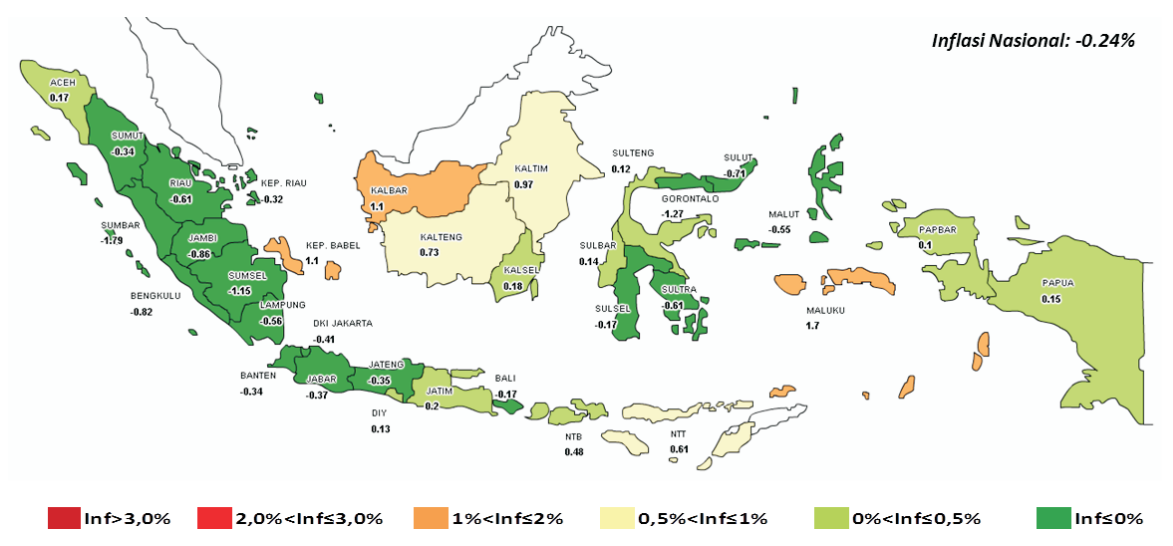

Gambar 2.

Peta Sebaran Inflasi IHK (\%, yoy) 


\section{Perkembangan Moneter}

Perkembangan suku bunga dan uang beredar masih sesuai dengan arah kebijakan moneter yang ditempuh Bank Indonesia. Selama triwulan IV 2014, suku bunga PUAB relatif stabil sementara suku bunga perbankan masih dalam tren yang meningkat. Peningkatan suku bunga, di tengah pertumbuhan ekonomi yang mengalami perlambatan pada triwulan IV 2014, kemudian memengaruhi dinamika likuiditas perekonomian. Perkembangan ini tercermin pada likuiditas di PUAB dan perbankan yang relatif stabil.

Pasar Uang Antar Bank pada triwulan IV 2014 ditandai oleh suku bunga PUAB O/N yang relatif stabil disertai rata-rata volume PUAB yang meningkat. Rata-rata tertimbang suku bunga PUAB O/N pada triwulan IV 2014 sebesar 5,81\% relatif stabil dibandingkan dengan triwulan sebelumnya sebesar 5,86\% (Grafik 13). Keketatan likuiditas di pasar uang relatif mereda yang tercermin dari menurunnya suku bunga PUAB dengan tenor yang lebih besar dari overnight, yang selanjutnya menurunkan spread PUAB untuk berbagai tenor terhadap overnight. Sejalan dengan meredanya keketatan likuiditas, volume rata-rata PUAB pada triwulan IV 2014 meningkat sebesar Rp12,9 triliun, lebih tinggi dibandingkan dengan triwulan sebelumnya sebesar Rp10,8 triliun.

Suku bunga perbankan pada triwulan IV 2014 masih dalam tren yang meningkat. Suku bunga rata-rata tertimbang (RRT) deposito yang sempat turun pada dua bulan pertama triwulan IV 2014 akibat membaiknya likuiditas dan penerapan OJK Cap, kembali meningkat pada Desember 2014 sebagai respons kenaikan BI Rate. Sejalan dengan kenaikan suku bunga deposito, suku bunga kredit meningkat walaupun dengan magnitude yang lebih rendah dan dengan lag waktu. Secara triwulanan, RRT suku bunga kredit meningkat sebesar 8 bps menjadi 12,95\% dari 12,87\%. Kenaikan suku bunga RRT kredit terutama disumbang oleh kenaikan suku bunga Kredit Konsumsi (KK) sebesar 20 bpsmenjadi 13,58\%. Suku bunga Kredit Modal Kerja (KMK) dan Kredit Investasi (KI) masing-masing hanya naik 1 bps menjadi $12,79 \%$ dan 2 bps menjadi 12,36\%. Dengan perkembangan tersebut, spread antara suku bunga kredit dan deposito 1 bulan pada triwulan IV 2014 menyempit menjadi 437 bps dari 439 bps seiring dengan kenaikan suku bunga deposito 1 bulan yang lebih tinggi daripada suku bunga kredit (Grafik 14). 


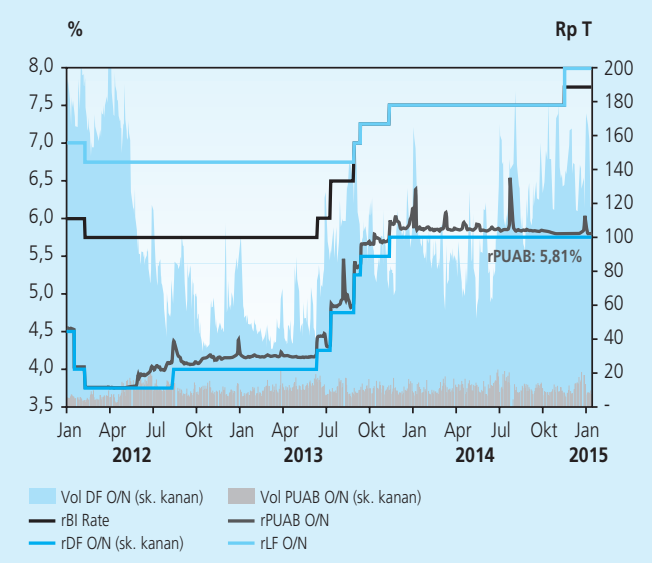

Grafik 13. Koridor Suku Bunga Operasional Moneter

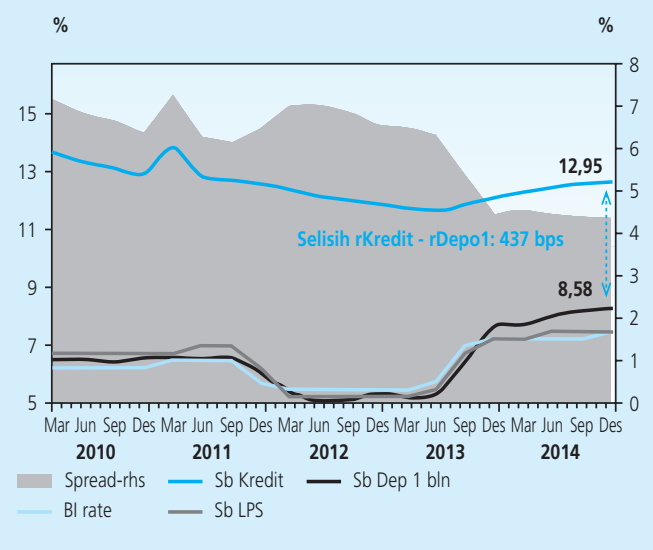

Grafik 14 Volume PUAB Total

Likuiditas perekonomian (M2) pada triwulan IV 2014 mengalami peningkatan terutama didorong oleh peningkatan uang kuasi. Pertumbuhan M2 pada triwulan IV 2014 meningkat menjadi 11,8\% (yoy) dari 11,7\% (yoy). Berdasarkan komponennya, peningkatan M2 terutama dikontribusi oleh kenaikan uang kuasi. Kenaikan suku bunga deposito dan menurunnya kegiatan ekonomi mendorong masyarakat untuk cenderung meningkatkan simpanan di perbankan. Di sisi lain, komponen M2 lainnya yakni M1 tumbuh melambat dari 9,4\% (yoy) menjadi 6,2\% (yoy) didorong oleh perlambatan pertumbuhan uang kartal dan simpanan giro rupiah, masingmasing menjadi 9,8\% (yoy) dan 9,1\% (yoy) dari 4,9\% (yoy) dan 7,3\% (yoy).

Berdasarkan faktor yang mempengaruhi, kenaikan M2 terutama bersumber dari peningkatan tagihan bersih kepada pemerintah pusat (NCG). Pada triwulan IV 2014, NCG tumbuh dari 1,0\% (yoy) menjadi 2,5\% (yoy) sejalan dengan siklus akhir tahun belanja pemerintah. Sementara itu, aktiva luar negeri bersih (NFA) mengalami perlambatan

\section{Industri Perbankan}

Stabilitas sistem keuangan tetap solid ditopang oleh ketahanan sistem perbankan dan relatif terjaganya kinerja pasar keuangan. Ketahanan industri perbankan tetap kuat dengan risiko kredit, likuiditas dan pasar yang cukup terjaga. Selain itu, ketahanan industri perbankan juga terpelihara, didukung oleh modal yang masih kuat.

Laju pertumbuhan kredit melambat terutama disumbang oleh kredit modal kerja (KMK). Pertumbuhan kredit pada triwulan IV 2014 kembali melambat menjadi 11,6\% (yoy) dari triwulan sebelumnya sebesar 13,2\% (yoy) (Tabel 2). Perlambatan laju kredit terutama disumbang oleh 
KMK yang tumbuh melambat dari 13,3\% (yoy) pada triwulan III 2014 menjadi 10,8\% (yoy) pada triwulan IV 2014. Sementara itu, KI Juga mengalami perlambatan dari 16,4\% (yoy) pada triwulan III 2014 menjadi 13,2\% (yoy) pada triwulan IV 2014. Berbeda dengan KMK dan KI, KK mencatat pertumbuhan yang meningkat dari 10,1\% (yoy) menjadi 11,5\% (yoy) pada triwulan IV 2014. Secara sektoral, perlambatan pertumbuhan kredit didorong oleh melambatnya pertumbuhan kredit di sektor perdagangan dan industri pengolahan, masing- masing melambat dari 13,9\% (yoy) dan 16,1\% (yoy) menjadi 12,4\% (yoy) dan 14,3\% (yoy).

Pertumbuhan Dana Pihak Ketiga (DPK) pada triwulan IV 2014 juga melambat. Pertumbuhan DPK pada triwulan IV 2014 tercatat sebesar 12,3\%, melambat dari triwulan sebelumnya sebesar 13,3\% (yoy). Perlambatan tersebut terjadi pada seluruh komponen DPK (Grafik 15).

\begin{tabular}{|c|c|c|c|c|c|c|c|c|c|c|c|c|c|}
\hline \multicolumn{14}{|c|}{$\begin{array}{c}\text { Tabel } 2 . \\
\text { Pertumbuhan Kredit }\end{array}$} \\
\hline & \multicolumn{6}{|c|}{ Pertumbuhan Kredit (\%) } & \multirow{2}{*}{$\begin{array}{l}\text { Share } \\
\text { Kredit } \\
\text { Des'14 }\end{array}$} & \multicolumn{6}{|c|}{ NPL (\%) } \\
\hline & $\begin{array}{c}\text { Rerata } \\
\text { 2008-2009 }\end{array}$ & $\begin{array}{c}\text { Rerata } \\
2010-2013\end{array}$ & Mar-14 & Jun-14 & Sep-14 & Des-14 & & $\begin{array}{c}\text { Rerata } \\
\text { 2008-2009 }\end{array}$ & $\begin{array}{c}\text { Rerata } \\
2010-2013\end{array}$ & Mar-14 & Jun-14 & Sep-14 & Des-14 \\
\hline Industri/Agregat & 24,9 & 22,1 & 19,45 & 17,20 & 13,16 & 11,58 & 100,00 & 3,75 & 2,48 & 2,00 & 2,16 & 2,29 & 2,16 \\
\hline \multicolumn{14}{|l|}{ Per Sektor Ekonomi } \\
\hline Perdagangan & 22,4 & 23,8 & 24,16 & 18,28 & 13,87 & 12,36 & 21,51 & 3,95 & 3,42 & 2,69 & 2,92 & 2,97 & 3,02 \\
\hline Lain-lain & 25,8 & 22,2 & 8,59 & 13,93 & 11,20 & 12,67 & 28,09 & 2,74 & 1,91 & 1,49 & 1,66 & 1,58 & 1,42 \\
\hline Industri & 16,6 & 19,2 & 26,20 & 24,90 & 16,08 & 14,30 & 17,98 & 6,46 & 3,33 & 2,13 & 2,00 & 2,15 & 1,86 \\
\hline Pengangkutan & 53,2 & 21,0 & 28,40 & 28,61 & 18,21 & 5,13 & 4,68 & 2,49 & 3,03 & 2,38 & 2,46 & 3,79 & 3,21 \\
\hline Konstruksi & 27,6 & 15,3 & 24,75 & 17,54 & 18,65 & 26,86 & 4,01 & 4,40 & 4,03 & 3,93 & 4,24 & 4,55 & 4,61 \\
\hline Pertanian & 24,5 & 22,5 & 24,46 & 25,44 & 21,66 & 19,90 & 5,99 & 3,54 & 2,02 & 1,70 & 2,13 & 2,09 & 1,83 \\
\hline Jasa Dunia Usaha & 27,6 & 21,5 & 19,53 & 6,18 & $(1,03)$ & $(3,68)$ & 9,03 & 2,29 & 1,45 & 1,35 & 1,29 & 1,23 & 1,49 \\
\hline Jasa Sosial & 19,0 & 53,9 & 24,35 & 14,31 & 19,51 & 19,22 & 2,66 & 3,35 & 3,21 & 2,11 & 2,48 & 2,88 & 2,25 \\
\hline Pertambangan & 35,5 & 38,0 & 13,81 & 6,97 & 17,05 & 11,83 & 3,86 & 2,91 & 1,19 & 1,94 & 2,49 & 3,22 & 2,52 \\
\hline Listrik & 85,2 & 36,4 & 41,41 & 19,53 & 21,09 & 2,06 & 2,21 & 0,25 & 0,50 & 0,85 & 1,06 & 1,28 & 1,91 \\
\hline \multicolumn{14}{|l|}{ Per Jenis Penggunaan } \\
\hline KMK & 23,1 & 21,1 & 16,58 & 17,30 & 13,33 & 10,83 & 47,83 & 4,02 & 2,92 & 2,36 & 2,44 & 2,55 & 2,49 \\
\hline $\mathrm{KI}$ & 28,4 & 26,0 & 34,64 & 22,46 & 16,40 & 13,16 & 24,58 & 4,59 & 2,37 & 1,86 & 2,27 & 2,60 & 2,35 \\
\hline KK & 25,8 & 21,3 & 12,93 & 12,72 & 10,14 & 11,51 & 27,59 & 2,72 & 1,86 & 1,49 & 1,57 & 1,57 & 1,41 \\
\hline
\end{tabular}




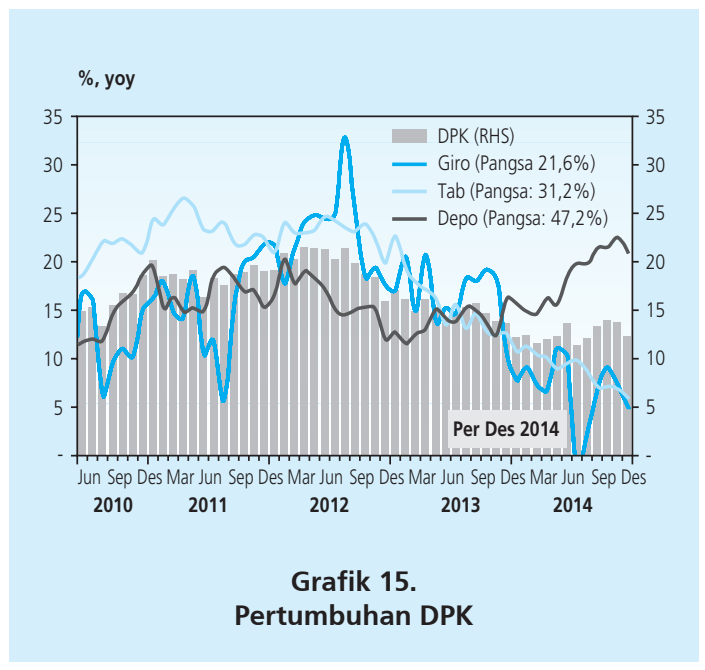

Kondisi perbankan masih cukup terjaga di tengah melambatnya pertumbuhan kredit. Pada triwulan IV 2014, ketahanan permodalan masih cukup memadai dengan rasio kecukupan modal (Capital Adequacy Ratio/CAR) sebesar 19,36\%. Sementara itu, dari sisi profitabilitas, ROA perbankan masih cukup baik sebesar 2,85\% (Tabel 3).

\begin{tabular}{|c|c|c|c|c|c|c|c|c|c|c|c|c|c|}
\hline \multicolumn{14}{|c|}{$\begin{array}{c}\text { Tabel } 3 . \\
\text { Perkembangan Nilai Sistem Pembayaran NonTunai }\end{array}$} \\
\hline \multirow{2}{*}{$\begin{array}{l}\text { Indikator } \\
\text { Utama }\end{array}$} & & \multicolumn{12}{|c|}{2014} \\
\hline & & Jan & Feb & Mar & Apr & Mei & Jun & Jul & Ags & Sep & Okt & Nov & Des \\
\hline Total Aset & (TRp) & $4,880.5$ & $4,888.8$ & $4,933.0$ & $5,008.1$ & $5,097.5$ & $5,198.0$ & $5,121.1$ & $5,218.9$ & $5,418.8$ & $5,445.7$ & $5,511.1$ & $5,615.1$ \\
\hline DPK & (TRp) & $3,594.7$ & $3,603.6$ & $3,618.1$ & $3,694.8$ & $3,763.5$ & $3,834.5$ & $3,778.4$ & $3,855.9$ & $3,995.8$ & $4,011.4$ & $4,054.7$ & $4,114.4$ \\
\hline Kredit* & (TRp) & $3,258.4$ & $3,267.8$ & $3,306.9$ & $3,361.3$ & $3,403.1$ & $3,468.2$ & $3,495.0$ & $3,498.4$ & $3,561.3$ & $3,558.1$ & $3,596.6$ & $3,674.3$ \\
\hline $\mathrm{LDR}^{*}$ & $(\%)$ & 90.6 & 90.7 & 91.4 & 91.0 & 90.4 & 90.4 & 92.5 & 90.7 & 89.1 & 88.7 & 88.7 & 89.3 \\
\hline NPLs Gross* & $(\%)$ & 1.9 & 2.0 & 2.0 & 2.0 & 2.2 & 2.2 & 2.2 & 2.3 & 2.3 & 2.3 & 2.4 & 2.2 \\
\hline CAR & $(\%)$ & 19.6 & 19.8 & 19.8 & 19.4 & 19.5 & 19.3 & 19.3 & 19.3 & 19.4 & 19.5 & 19.6 & 19.4 \\
\hline NIM & $(\%)$ & 4.1 & 4.1 & 4.3 & 4.3 & 4.2 & 4.2 & 4.2 & 4.2 & 4.2 & 4.2 & 4.2 & 4.2 \\
\hline ROA & $(\%)$ & 2.8 & 2.7 & 2.9 & 2.9 & 2.9 & 2.9 & 2.8 & 2.8 & 2.8 & 2.8 & 2.8 & 2.8 \\
\hline
\end{tabular}

\section{Pasar Saham dan Pasar Surat Berharga Negara}

Perkembangan pasar saham domestik selama triwulan IV 2014 menunjukkan kinerja positif didorong oleh sentimen positif domestik. Kinerja IHSG triwulan IV2014 mencapai level 5.226,95 (31 Desember 2014) atau naik sebesar 1,7\% (qtq) dibandingkan dengan triwulan III 2014 sebesar 5.137,60 (Grafik 16). Penguatan ini dipicu oleh sentimen positif investor atas proses 
transisi kepemimpinan yang berjalan lancar. Selain itu, kebijakan pemerintah menaikkan harga BBM (17 November 2014) yang diikuti oleh kenaikan BI Rate sebesar 25 bps turut direspons positif di bursa. Namun demikian, antisipasi investor global atas hasil FOMC pada pertengahan Agustus yang cenderung hawkish, memberi tekanan pada pasar saham. Tekanan terhadap pasar saham berkurang dan kembali menguat setelah hasil FOMC menyatakan bahwa the Fed akan menunda kenaikan suku bunga acuan. Jika dibandingkan dengan bursa saham kawasan (Vietnam, Filipina, Thailand, dan Malaysia), pasar saham Indonesia selama triwulan IV 2014 mencatat kinerja yang cukup baik. Bursa Indonesia mencatat pertumbuhan positif, sementara bursa saham kawasan mencatat pertumbuhan negatif.

Kinerja pasar SBN meningkat didorong oleh sentimen positif domestik. Sentimen positif domestik akan proses transisi kepemimpinan paska pemilu yang berjalan lancar dan kondusif serta kebijakan BI untuk menaikkan BI Rate sebagai antisipasi kenaikan inflasi akibat kenaikan harga BBM mendorong positifnya kinerja pasar SBN. Namun demikian, tren penguatan tertahan oleh sentimen negatif eksternal yang berasal dari perlambatan ekonomi Jepang dan Tiongkok, penurunan harga minyak yang terjadi menjelang akhir tahun 2014, dan antisipasi investor global atas hasil FOMC pada pertengahan Agustus 2014 yang cenderung hawkish. Lebih lanjut, hasil FOMC yang menyatakan bahwa the Fed akan menunda kenaikan suku bunga acuan mendatangkan sentimen positif bagi pasar SBN domestik. Investor global kembali masuk ke pasar obligasi domestik sehingga mendorong yield SBN kembali turun hingga akhir tahun 2014. Secara keseluruhan, selama triwulan IV 2014 yield menurun sebesar 57 bps menjadi 7,80\% dibandingkan dengan triwulan III 2014 sebesar 8,37\% (Grafik 17). Yield jangka pendek, menengah dan panjang turun masing-masing sebesar 35 bps, 65 bps dan 70 bps menjadi sebesar 7,41\%, 7,78\% dan 8,36\%.

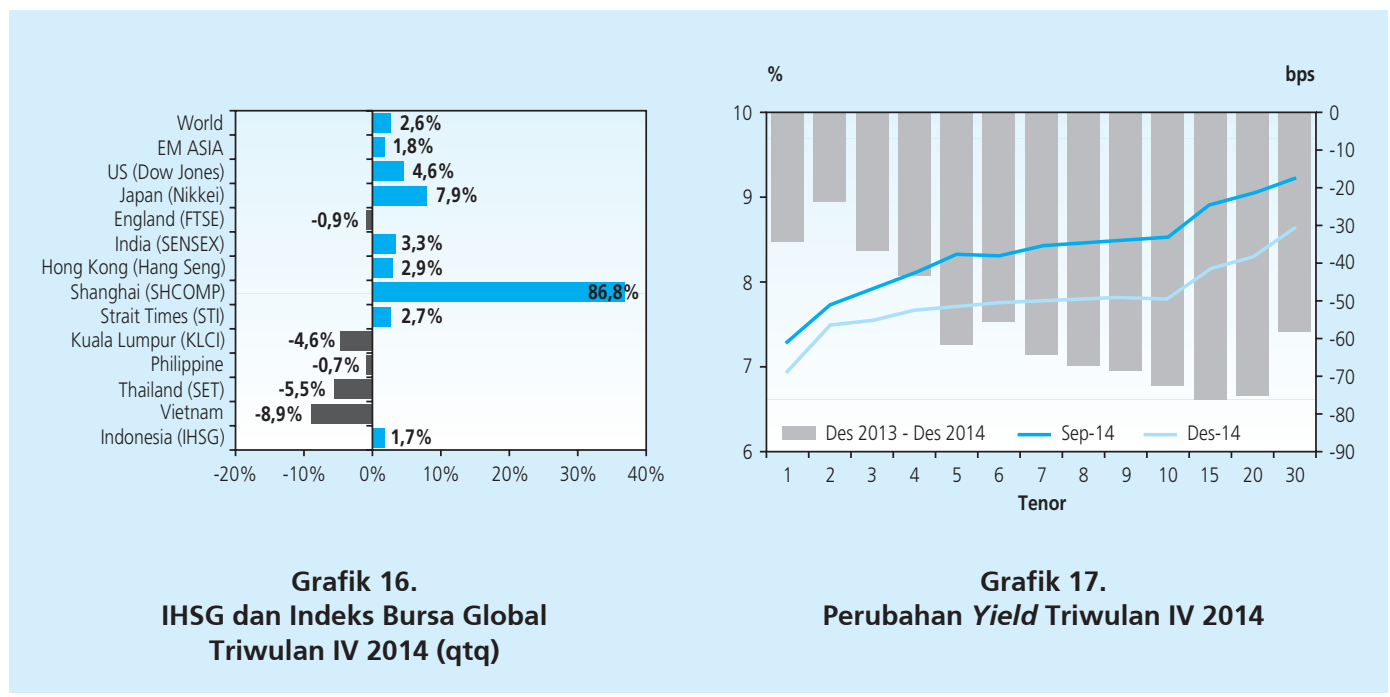


Kinerja pasar SBN yang positif sejalan dengan perilaku investor asing yang mencatat net beli. Selama triwulan IV 2014, nonresiden tercatat masih melakukan pembelian di pasar SBN meskipun dengan jumlah net beli yang mengalami penurunan dibandingkan dengan triwulan III 2014. Nonresiden tercatat melakukan net beli sebesar Rp13,99 triliun atau turun dibanding triwulan III 2014 dengan total pembelian sebesar Rp43,79 triliun. Penurunan ini didorong oleh aksi jual nonresiden terutama di bulan Desember 2014 yang dipicu sentimen negatif eksternal dengan total net jual yang mencapai Rp19,84 triliun. Dibandingkan dengan beberapa negara kawasan, hingga triwulan IV 2014, yield Indonesia tercatat lebih tinggi. Hal ini seiring dengan tekanan yang terjadi pada pertengahan bulan Desember 2014 ditambah dengan tingginya inflasi di bulan Desember 2014.

Selama triwulan IV 2014, kepemilikan asing pada pasar SBN meningkat. Kepemilikan asing pada triwulan IV 2014 mencapai 37,04\%, lebih tinggi dibandingkan dengan triwulan III 2014. Aksi beli SBN oleh asing terjadi di seluruh tenor dengan pembelian terbanyak pada tenor panjang (Grafik 1.47). Kepemilikan SBN oleh bank dan asuransi menurun menjadi $29,45 \%$ dan $12,09 \%$ dibandingkan dengan triwulan sebelumnya. Porsi kepemilikan SBN oleh dana pensiun relatif stabil, sementara porsi kepemilikian SBN oleh Bank Indonesia meningkat.

\section{Perkembangan Sistem Pembayaran}

Perkembangan sistem pembayaran di kelompok uang tunai secara umum sejalan dengan perkembangan ekonomi domestik, khususnya dari sektor konsumsi rumah tangga. Rata-rata harian Uang Kartal yang Diedarkan (UYD) pada triwulan IV 2014 adalah sebesar Rp478,6 triliun atau tumbuh $6,8 \%$ (yoy), menurun dibandingkan dengan pertumbuhan triwulan sebelumnya sebesar $12,6 \%$ (yoy). Perkembangan UYD ini sejalan dengan melambatnya pertumbuhan konsumsi rumah tangga.

Di tengah tren pertumbuhan UYD yang melambat tersebut, Bank Indonesia terus berupaya meningkatkan kelayakan uang yang beredar. Selama triwulan IV 2014, sejumlah 1,5 miliar lembar/keping Uang Tidak Layak Edar (UTLE) senilai Rp30,7 triliun telah dimusnahkan dan diganti dengan uang rupiah yang layak edar. Jumlah pemusnahan UTLE tersebut lebih tinggi dibandingkan dengan triwulan III 2014 yang tercatat sebesar 1,3 miliar lembar/keping atau senilai dengan Rp29,7 triliun. Meningkatnya pemusnahan UTLE tersebut disebabkan oleh meningkatnya jumlah uang dalam kondisi tidak layak edar, meskipun jumlah uang yang disetorkan oleh perbankan ke Bank Indonesia mengalami penurunan.

Transaksi sistem pembayaran tetap dapat berjalan secara aman dan lancar selama triwulan IV 2014. Dibandingkan dengan triwulan sebelumnya, transaksi sistem pembayaran nontunai pada triwulan IV 2014 mengalami peningkatan baik dari sisi nilai maupun volume transaksi apabila. Peningkatan nilai transaksi tercatat sebesar Rp4.526,9 triliun atau meningkat sebesar 11,0\% (qtq) (Tabel 4), sedangkan peningkatan volume transaksi tercatat sebesar 63,1 
juta transaksi atau 5,3\% (qtq). Secara umum, peningkatan nilai transaksi terjadi pada seluruh kelompok transaksi terutama transaksi Operasi Moneter yang meningkat sebesar Rp2.483,0 triliun atau naik 15,0\% dibandingkan dengan triwulan sebelumnya. Di sisi lain, peningkatan jumlah volume transaksi lebih disebabkan oleh meningkatnya transaksi masyarakat melalui instrumen nontunai khususnya yang diselenggarakan oleh industri. Adapun peningkatan jumlah volume transaksi terbesar terjadi pada transaksi Alat Pembayaran dengan Menggunakan Kartu (APMK) yang meningkat sebesar 43,6 juta transaksi atau 3,9\% (qtq).

\begin{tabular}{|c|c|c|c|c|c|c|c|}
\hline \multicolumn{8}{|c|}{$\begin{array}{l}\text { Tabel } 4 . \\
\text { Perkembangan Nilai Sistem Pembayaran NonTunai }\end{array}$} \\
\hline \multirow{2}{*}{$\begin{array}{l}\text { Transaksi Sistem Pembayaran } \\
\text { Non Tunai }\end{array}$} & \multicolumn{2}{|c|}{2013} & \multicolumn{4}{|c|}{2014} & \multirow{2}{*}{\begin{tabular}{|l}
$\%$ naik/(turun) \\
QtQ (III to IV)
\end{tabular}} \\
\hline & Q-III & Q-IV & Q-I & Q-II & Q-III & Q-IV & \\
\hline BI-RTGS & $26.369,5$ & $24.403,8$ & $23.817,8$ & $24.150,4$ & $29.872,4$ & $33.041,6$ & $10,6 \%$ \\
\hline BI-SSSS & $8.259,9$ & $8.233,4$ & $7.173,6$ & $6.396,9$ & $9.366,8$ & $10.636,7$ & $13,6 \%$ \\
\hline Kliring & 680,8 & 708,0 & 667,8 & 710,7 & 716,4 & 770,9 & $7,6 \%$ \\
\hline Debet & 421,2 & 425,6 & 399,1 & 417,9 & 411,9 & 432,3 & $5,0 \%$ \\
\hline Kredit & 259,6 & 282,4 & 268,7 & 292,8 & 304,5 & 338,6 & $11,2 \%$ \\
\hline APMK & $1.039,4$ & $1.073,9$ & $1.077,3$ & $1.158,5$ & $1.215,5$ & $1.248,8$ & $2,7 \%$ \\
\hline Kartu Kredit & 57,1 & 59,6 & 56,9 & 63,6 & 65,1 & 69,4 & $6,7 \%$ \\
\hline Kartu ATM dan ATM/Debet & 982,4 & $1.014,3$ & $1.020,5$ & $1.094,9$ & $1.150,4$ & $1.179,3$ & $2,5 \%$ \\
\hline Uang Elektronik & 0,9 & 0,7 & 0,7 & 0,8 & 0,9 & 0,8 & $-15,5 \%$ \\
\hline Total & $36.350,5$ & $34.419,8$ & $32.737,2$ & $32.417,4$ & $41.172,0$ & $45.698,9$ & $11,0 \%$ \\
\hline
\end{tabular}

Selaras dengan peningkatan nilai dan volume transaksi sistem pembayaran non tunai pada triwulan IV 2014, transaksi pembayaran yang diselesaikan melalui Sistem BI-RTGS juga mengalami peningkatan baik dari sisi nilai maupun volume. Ketersediaan sistem Bank Indonesia Real Time Gross Settlement (BI-RTGS) sebagai setelmen dana, BI-SSSS sebagai setelmen surat berharga pemerintah dan Bank Indonesia, serta SKNBI mencapai 100\% pada triwulan III 2014. Nilai transaksi pembayaran yang diselesaikan melalui Sistem BI-RTGS meningkat sebesar Rp3.169,3 triliun (QtQ naik sebesar 10,6\%) dibandingkan dengan triwulan sebelumnya yang tercatat sebesar Rp29.872,4 triliun menjadi sebesar Rp33.041,6 triliun. Sementara volume transaksi pembayaran yang diselesaikan melalui Sistem BI-RTGS meningkat sebesar 60 ribu (QtQ naik sebesar 1,3\%) dibandingkan dengan triwulan sebelumnya yang tercatat sebanyak 4,52 juta transaksi menjadi sebanyak 4,58 juta transaksi.

\section{Prospek Perekonomian}

Bank Indonesia memperkirakan pertumbuhan ekonomi pada tahun 2015 lebih tinggi dari tahun 2014 yaitu pada kisaran 5,4-5,8\%. Peningkatan tersebut terutama disebabkan 
oleh masih kuatnya konsumsi rumah tangga dan kontribusi positif dari peningkatan kapasitas fiskal untuk mendukung kegiatan ekonomi produktif, termasuk pembangunan proyek-proyek infrastruktur. Hal tersebut telah dicanangkan oleh pemerintah, sebagaimana tertuang dalam APBNP 2015 yang telah disetujui DPR. Selain itu, langkah-langkah perbaikan iklim investasi yang dilakukan Pemerintah, termasuk pelayanan terpadu perijinan satu pintu (PTSP), juga diperkirakan dapat membantu mendorong aktivitas investasi lebih lanjut. Kontribusi ekspor terhadap pertumbuhan juga diprakirakan akan meningkat meskipun belum signifikan.

Inflasi pada 2015 diperkirakan lebih rendah dibandingkan tahun 2014 dan berada dalam kisaran sasaran bawah sasaran inflasi. Hal ini didukung oleh terkendalinya inflasi inti, menurunnya harga minyak dunia, dan membaiknya pasokan bahan pangan. Terkendalinya inflasi inti diperkirakan didorong oleh terjaganya ekspektasi inflasi, harga komoditas internasional yang relatif rendah, serta relatif minimalnya tekanan dari sisi permintaan. Menurunnya harga minyak dunia dan perbaikan pasokan bahan pangan diperkirakan akan mengakibatkan relatif rendahnya tekanan inflasi administered prices dan volatile food relatif. Dengan perkembangan tersebut, inflasi di akhir tahun 2015 diprakirakan berada di kisaran bawah sasaran $4 \pm 1 \%$. Sementara itu, dengan koordinasi kebijakan Bank Indonesia dan Pemerintah yang terukur, inflasi pada akhir tahun 2016 diprakirakan berada dalam kisaran target 4+1\%.

Bank Indonesia akan terus mencermati beberapa risiko perekonomian domestik, meskipun sebagian dari risiko-risiko tersebut diperkirakan dapat diminimalisir dengan berbagai langkah reformasi struktural yang dilakukan Pemerintah dan Bank Indonesia. Dari sisi global, risiko terkait dengan rencana normalisasi kebijakan the Fed sebagian dapat diimbangi dengan rencana respon kebijakan stimulus moneter Eropa. Struktur fiskal yang lebih baik dan berkualitas juga dapat mendorong arus masuk modal asing. Sementara itu, langkah reformasi struktural, diharapkan dapat lebih meningkatkan daya saing ekspor, sehingga dapat mengurangi dampak pelemahan ekspor akibat risiko perlambatan Tiongkok. Di sisi internal, risiko terkait inflasi relatif minimal, sejalan dengan penurunan harga komoditas dan minyak di tengah minimnya inflasi dari sisi permintaan dan kebijakan ketahanan pangan Pemerintah. 